\title{
The Effect of the Perception of Deposit Bank Rate, Quality of Service, and the Using of Banking Technology towards Rural Fellow's Interest to Save Money in Bank Rakyat Indonesia Inc. Unit Wates - Blitar
}

\author{
Ria Prasetyo ${ }^{1}$, Dwi Wulandari ${ }^{1} \&$ Imam Mukhlis $^{1}$ \\ ${ }^{1}$ Faculty of Economics, Universitas Negeri Malang, Malang, East Java, Indonesia \\ Correspondence: Dwi Wulandari, Faculty of Economics, Universitas Negeri Malang, Malang, East Java, Indonesia.
}

Received: December 1, 2015

doi:10.5430/ijfr.v7n1p130
Accepted: December 18, $2015 \quad$ Online Published: January 11, 2016

URL: http://dx.doi.org/10.5430/ijfr.v7n1p130

\begin{abstract}
Foster interest in saving in the community can be a mean to improve economic conditions. Excess funds owned by the public can be channeled to those who lack funds through banking institutions. There are several factors that affect a person's interest to save. In the study, there are three free variables namely interest rates of savings, service quality, and the use of banking technology. This research was done by taking sample from one population (people in Wates District, Blitar Regency), the taken sample is the customers of Bank Rakyat Indonesia Corp. The research design of this research is explanatory descriptive design and the descriptive approach correlation were used to describe, explain, or present the data from perception variable of deposit bank rate, service quality, and banking technology towards people interest to save their money in Bank Rakyat Indonesia Corp. Unit Wates. The used method in sample taking in this research uses simple random sampling which found 99 customers to be given questionnaire. From the result of analysis the perception of bank rate doesn't affect rural fellows' interest in saving money to Bank Rakyat Indonesia Corp. Unit Wates-Blitar. Service quality affects people's interest in the village to save money in Bank Rakyat Indonesia Corp. The perception of bank rate, service quality, and banking technology implementation influence village people's willingness to save their money to Bank Rakyat Indonesia Corp. Unit Wates-Blitar.
\end{abstract}

Keywords: the perception of deposit bank rate quality of service, banking technology, interest to save money

\section{Introduction}

The implication of people's needs for financial service arises and becomes more various, the role of banking becomes more urgent for people in every level, whether in the advanced countries or the developing countries. Banking nowadays has become better improved, whether in the terms of products variety, service quality, or implemented technology. Banking becomes more dominating the economic and business development of a country. Furthermore, the activity and availability of banking really determines the growing of a country due to economic factor. Because of that, it would be surprised that if the banking of a country broken down, then it will led to the falling of the country's economy like what had happened to Indonesia in 1998 and 1999 (Kasmir: 2012).

The spread of information is vital due to the latest improvement in banking. For those people who lived in a city, information can be easily obtained from many kinds of media, both printed or electronic, contrary to those who lived in village or rural area who hardly get informed. In this study, the chosen region is Wates District of Blitar Regency under several reasons, among them is perspected the geographical condition that considered as coastal, bacause located in the southern hemisphere of Blitar Regency. This study focused on the rural fellows since generally they have no any specific pattern in their lifestyle, especially in economic and banking sector. The knowledge of these rural fellows is also can be said as ack if compared to the citizen in term of banking sectors. The existence of banking corporations in village plays a determining role for the economic condition the area. As an intermediator institute, bank brings an important function in economy and form an ace for the development of an area.

Indonesia is a country which its society formed by multi differents background of culture, education, and social condition. Each region possesses their unique traits and character which vary to others, so the lifestyle and social condition also present a wide range. Those differences also can be seen between rural fellows and citizens which show different economic social condition and lifestyle. Generally, citizen has higher education and well managed economic life. The knowledge and ability to access for banking corporation are aso easy to get since there are many 
banking corporations in city. The limit amount of banking corporation in village is one factor that causes the limited knowledge of financial in the people. There still many people who save their money in conventional ways, for example keep it in home. That conventional lifestyle also brings conventional pattern in managing their finance so people are more unwilling to access the available banking unit. Yet, those who are already access the banking system still have no interest or attention to the advantaging sectors.

Bank rate functioned as the interest point for customer with more fund to invest. According to the opinion from Prasetiantono (2000) on bank rate is if the bank rate is high, customer will be more likely to put in their money in the bank because they can wish for a good return. Basically, interest is roled as main stimulator for people to put their fund in bank. The amount of deposit will be determined by the level of bank rate. The higher the deposit bank rate, the higher the interest of people to put in their fund and vice versa. That condition must be supported by the updated information on bank rate since it often changes. The limit usually happens in the people in village on the bank rate, while generally have no idea if deposit bank rate in bank can be raise or depreciate over the time following the economic condition. Moreover, not everyone pay attention the condition of bank rate on the time the put their money.

The quality of service is one of media that can be used by bank to attract people's attention. Offering the finest service is expected to satisfy customers so they will achieve pleasure and the will to deposit their money will increase. According to Lupiyoadi (2001:147) one thing that determines the success and quality rate of a corporation is the ability of the corporation in giving service to their customers. The success of a corporation in giving a qualified service to the customers will rewards to the high segment in the market and also increasing the profit of corporation. In banking, the quality of service also considered as essential since it is able to lead to better segment in the market.

The advance of technology in banking resulted positive in the easy and quick access in banking transaction. With this developed technology, customers are being able to do banking transaction everywhere and anytime. The forms of technology advance in banking today are internet access (e-banking), mobile access (m-banking), telephone access (phone-banking), and short message access (sms-banking). By providing facilities and accessibility through technology, it is expected to increase people's interest using and access bank. Each form of provided advancements is adjusted as the customer's needs and request. People as bank costumer have many different and various needs and interest. For citizens, technology advancement surely aids and supports their works that demand fast response.

The provided easiness by bank becomes one important value to attract costumers to invest their money and utilizes those facilities. The rural fellows are different to the citizens. The background of education, job, needs, and also cultural and social condition are the differentiate factors. The technology advancement is not instantly can be implemented by rural fellows. Some people who have acquired high education are able to to see the technology advance and its facilities well. Yet, in the rural fellows still there is a gap in the education level. Generally, the education level of rural fellows is still in the below to middle level and cannot follow the technology advance immediately.

Stimulating people's interest in saving money in bank can be a way to improve economic condition in the society. The surplus of fund in the people can be distributed to those in needs through bank. Beside that, the people also will get advantage in form of interest of the deposit and safety for their money. This research was done to know how big is the implication of bank rate, service quality, and technology advance in banking towards people's willing to save their money in bank in Wates Village, Blitar Regency to Bank Rakyat Indonesia Corporate Unit Wates. The background of education, culture, and economic social condition of Wates Village people that differs to the citizens is one of reason in selecting location for this research.

\section{Research Method}

This research was done by taking sample from one population (people in Wates District, Blitar Regency), the taken sample is the customers of Bank Rakyat Indonesia Corp. which lived in the area of Wates District, Blitar Regency, and use qustionnaire as the main instrument in data collection, to explain the influence between each variables through hipothesis test and which variable gives the biggest influence.

The research design of this research is explanatory descriptive design and the descriptive approach correlation were used to describe, explain, or present the data from perception variable of deposit bank rate, service quality, and banking technology towards people interest to save their money in Bank Rakyat Indonesia Corp. Unit Wates. While the correlation approach was used to explain the most influencing variable towards people interest in saving their money to Bank Rakyat Indonesia Corp. Unit Wates. The used method in sample taking in this research uses simple random sampling which found 99 customers to be given questionnaire. Researcher randomly select sample from the 
population based on probability frequency of the entire population member, in this case is the people in the village that become customers to Bank Rakyat Indonesia Corp. Unit Wates-Blitar.

\section{Result and Discussion}

From the result of analysis, it was known that the perception of bank rate doesn't make a significant influence towards people interest in saving money in bank. That condition can be caused by many factors such as the lack in understanding of financial literation in this people, low level of income, and the life condition that still considered as traditional. The lifestyle of these rural fellows also determines how big their willingness is to keep their money in bank. Access to bank was also already good, but still doesn't give significant influence for people to keep their money in bank. That condition can be seen from the phenomenon when people's decision to put their money in bank is not decrease when bank rate is low. On the other words, bank rate influences people's decisions to put their surplus money, but the interest of deposit is not the main motivation of their decision.

According to Prasetiantono (2000) on bank rate is: "if the bank rate is high, people will be more likely to put in their money since they can wish for a good return. This condition has a good effect towards people's interest in keeping their money in bank. If the bank rate is high, people's interest in putting in their fund will also will be high.” Though, from the result of this research, bank rate is known that it has no significant effect to the interest of saving money in bank. The village people's lifestyle and saving method is remain traditional and still has no any idea of saving money as an investment.

Several studies that already have been done found many different motivations of saving money in bank. Katona (1975) found that in USA around 1960's, people save their money in bank under the reason of for emergency situations (sick, unemployment), for reserving back up for other needs, future, or retirement, for children's needs, for buying a house or a long-period stuffs, and for entertainment. Only a few that say saving money for better return in the future and to inherit their money. The latest finding by Kotlikoff (1989) states that around 30\% family savings in USA can be explained through motive precautionary nature, for example as the implication of his anxiety to the coming age. This also found in Netherland and Sweden. The result of this study has a sync with theories above that bank rate or deposit interest is not the main motivation of saving money in bank. People usually put their money in bank as a reserve for unpredictable events and more likely to save money for their children.

From the analysis result, it can be known that service quality influences people's interest in village to save their money in bank. This is because of the behavior and cultural condition in the village that still appraises manner and courtesy. Village people are really appreciate hospitality and care to their surroundings. By achieving hospitality and a good care, people will be more comfortable to that environment.

Kotler (2002:83) also said that service is any action that can be offered by one to the other, that basically is invisible and resulted to no claim. Service is the attitude of producer in term of fulfilling consumer's needs and wishes in purpose to satisfy the consumer. Kotler also said that this attitude can happen before, on, or post the transaction. Generally, a high level service will results in high satisfaction and more intensive re-buy. Based on that condition, to achieve customer's trust and loyalty, it needs to make the customer feels comfortable. This comfortable feeling can be gained from the fine service of the bank unit to the customers.

According to Zeithaml (1990: 21), an excellent service quality will affect customer in the way of satisfaction to the customer. Service to customer is not only a procedure bu must pay more attention to the satisfaction of the customer. By obtaining satisfaction it will automatically increase people's willingness to save their money in bank. As been shown in this research, a good quality service really influences people's interest in saving money in bank, especially people in village which respect hospitality so much.

From the result of analysis, it can be known that technology implementation affects people's interest in saving money in bank. This is because the implemented technology such as internet banking, mobile banking, and Automatic Teller machine (ATM) really gives easy access to customer in doing transaction in bank. Not only citizens that able to use the facilities but also rural fellows can use them since they are available in the area to support their transaction quickly and efficiently. This thing can be separated from the role of bank unit in educate customer in making advantage of technologies and facilities in the area. Education and advocation on the facilities are also given to the new customers who are not familiar or just know the technology. The study also shows that people can accept and use the banking technologies. The rural condition is not a serious handicap in implementing and applying the technologies.

According to Maryanto Supriyono (2011:65) the fast advance of computer technology whether the hardware, software, host-to-host system, web system, and data communication contributes very well in banking sector 
electronically. Based on that theory, this research proes that technology advancement in banking gives a significant influence to people's interest to save their money in bank in the village. By the more advanced technology, people then will carefully select which they will trust to save their surplus fund.

From the result of analysis it can be seen that bank rate, service quality, and banking technology implementation silmutaneously affects people's interest to save their money in bank. This is because of bank rate stimulates village people's interest to put in their fund in bank. However, this study also found that bank rate is not the main motivation of people to invest their money in bank. Rural fellows tend to deeply respect manner and courtesy, which also pa attention to the service quality given by bank. A good and service gives a comfort feeling and participates in increasing people's interest to the bank.beside that, banking technology is also a vital factor which affect people's interest in saving their money in bank. It can be noticed from the result of this study which shows that availability and easy access to the technology such as ATM also forms a stimulation to people to save their money in bank.

The result of research conducted by Ratnasari (2013) on The Effect of Service Quality Towards Customers Satisfaction in Bank Rakyat Indonesia Corp. Unit Sawojajar Malang shows that the quality of service really affects customer's satisfaction. Customer's satisfaction will lead to the customer's interest to put in their money to the bank. The result of study done by Ratnasari (2013) is really relevant to this research where the variables of service quality becomes one variable that influences more in the research. Mahfiyah (2012) study on The Influence of Bank Rate and Rewards Towards Customer's Decision in Saving Their Money in Bank Rakyat Indonesia Corp. Malang Branch Martadinata. The result of research shows that bank rate positively and significantly influences customer's decision to put in their money. This condition might be affected by the different background of rural fellows to the citizens as according to each locations of research.

There are some factors that might influence someone's decision before saving the money in bank. According to Kotler (2002) factors that may affect in saving money in bank are bank rate, offered service, strategic location, the sales ability, and advertisements. Simultaneously, bank rate, service quality, and banking technology implementation affect's people's interest of saving money in bank in the village. The result of this research is relevant to theory stated by Kotler on the factors that affects motive in purchasing a product. Other than that, this result is also relevant to previous research by Mahfiyah (2012) where bank rate and rewards also significantly affect customer's decision in investing their fund to Bank Rakyat Indonesia (Persero) Corp. Malang Branch Martadinata.

\section{Conclusion}

The perception of bank rate doesn't affect rural fellows' interest in saving money to Bank Rakyat Indonesia Corp. Unit Wates-Blitar. Theoretically it was stated that high bank rate will be followed by a high interest of people to put in their money in the bank. However, in this case, bank rate and deposit interest are not the main motive of people to put in their money to bank, since if the bank rate deflate, the rate of money saving by customer is not decrease. So, partially, bank rate doesn't significantly affect people's interest to save money in bank.

Service quality affects people's interest in the village to save money in Bank Rakyat Indonesia Corp. Unit Wates-Blitar. The better the service, the higher people's interest. This is because people who feel comfortable to the service will repurchase the product, or in this case, will re-invest their moey to the bank. The quality of service really affects customer's willingness to put in their surplus fund.

The implementation of banking technology also affects people's interest to save their money to Bank Rakyat Indonesia Corp. Unit Wates-Blitar. The availability and advancement of banking technology inflict people's willingness to save put their money in bank. The easier the facilities, the more people get attracted to put in their money.

The perception of bank rate, service quality, and banking technology implementation influence village people's willingness to save their money to Bank Rakyat Indonesia Corp. Unit Wates-Blitar. Higher the bank rate, better the offered service, and easier the implemented banking technology, then people's interest in saving their money in bank will raising. This is because of bank rate is a stimulation for people to keep their money in bank. Other than that, good service determines people's decision as customer to trust their money to the bank or not. Service and availability of proper technology as people's needs also contributes in increasing people's interest to put in their surplus fund to the bank. So, those variables altogether influence people's interest to trust their money to Bank Rakyat Indonesia Corp. Unit Wates-Blitar. 


\section{Recommendation}

For further research, researches should incorporate more variables so that the conclusion will be clearer and the respondents should be wider from all class of depositor and all types of saving. The bank should increase the service quality in order to gain more depositors and to be able to grow more in the future.

\section{References}

Amstrong, G., \& Philip, K. (2002). Dasar-dasar Pemasaran. Jilid 1. Alih Bahasa Alexander Sindoro dan Benyamin Molan. Jakarta: Penerbit Prenhalindo.

Kasmir. (2012). Bank dan Lembaga Keuangan Lainnya. Jakarta: Raja Grafindo Persada

Katona, G. (1975). Psychological economics. New York: Elsevier.

Kotler, P. (2001). Manajemen Pemasaran: Analisis, Perencanaan dan Implementasi Dan Kontrol, Jilid I. Jakarta : Erlangga

Kotlikoff, L. J. (1989). What determines savings? Cambridge, MA: The MIT Press.

Mahfiyah, S. (2012). Pengaruh tingkat suku bunga dan pemberian hadiah terhadap keputusan nasabah dalam menabung pada PT. Bank Rakyat Indonesia (Persero) Tbk Malang Cabang Martadinata. Malang: Universitas Negeri Malang.

Prasetiantono. (2000). Keluar Dari Krisis: Analisis Ekonomi Indonesia. Jakarta: Gramedia Pustaka Utama.

Rambat, L. (2001). Manajemen Pemasaran Jasa (Teori dan Praktik). Salemba Empat. Jakarta.

Ratnasari, Ika Deviana. (2013). Efek kualitas layanan terhadap tinkat kepuasaan nasabah PT bank rakyat Indonesia (persero) Tbk unit Sawojajar Malang. Malang: Universitas Negeri Malang.

Supriyono, M. (2011). Buku Pintar Perbankan. Yogyakarta: Andi.

Zeithaml, V. A. (1990). Delivering Quality Service. New York. The Free Press. 